\title{
Analisis Penerapan PSAK No. 18 Pada Laporan Keuangan PT. Bank BNI (Persero)
}

\author{
Nurfitriana dan Desi Erianti \\ Program Studi Akuntansi, Sekolah Tinggi Ilmu Ekonomi Kesatuan \\ Bogor, Indonesia \\ E-Mail: s2.nurfitriana.1213@gmail.com
}

\begin{abstract}
Financial Institution Pension Fund Bank BNI is one of the Banks that organizes a Defined Contribution Pension Program with the main activity of holding a Pension Program whose contribution amount is determined based on the ability of participants. The Pension Program organized by the Financial Institution Pension Fund (DPLK) of BNI provides pension benefits that will be received after participants enter retirement age based on the amount of the contribution, length of participation and the rate of growth of funds during the membership period. Pension benefits are paid on a pension basis with cash refund. As a Pension Fund company, PT. Bank Negara Indonesia (Persero) must refer to the provisions / regulations / standards in the determination and management of pension funds specifically PSAK No. 18 governing the retirement benefit program. Presentation of Retirement Benefit Programs in Pension Fund Financial Reports in 2012-2013 PT. Bank Negara Indonesia (Persero) is in accordance with the Statement of Accounting Standards (PSAK) No. 18. Therefore, this study aims to determine the suitability of the application of Financial Accounting Standard Number 18 on the Reporting of Bank Negara Indonesia Pension Fund (Persero).
\end{abstract}

Keywords: pension fund accounting, PSAK no. 18.

\section{PENDAHULUAN \\ Latar Belakang}

Adanya program manfaat purnakarya memungkinkan terbentuknya suatu akumulasi dana yang dibutuhkan untuk memelihara kesinambungan penghasilan peserta program manfaat purnakarya. Keyakinan akan adanya kesinambungan penghasilan menimbulkan ketentraman kerja, sehingga akan meningkatkan motivasi kerja. Selain itu, loyalitas terhadap perusahaan juga akan meningkat. Penyelenggaraan program manfaat purnakarya dilakukan dengan mengupayakan manfaat purnakarya bagi pesertanya melalui suatu sistem pemupukan dana. Hampir seluruh program yang dilaksanakan mengambil bentuk badan hukum yayasan tapi baru-baru ini yayasan sudah beralih sebagai lanjutan yayasan yang disebut Perusahaan Dana Pensiun yang bergeraknya dalam lingkup sebagai lembaga penunjang perusahaan.

Dana pensiun diselenggarakan untuk memberikan kesejahteraan pada karyawan. Oleh karenanya baik instansi pemerintah maupun instansi swasta mengadakan program pensiun bagi para pegawainya, dan diharapkan dengan adanya program pensiun ini maka akan memberikan motivasi yang tinggi bagi karyawan sehingga akan memberikan keuntungan baik bagi perusahaan maupun pihak karyawan. Dana pensiun ditabung bukan untuk dinikmati sekarang melainkan dinikmati di masa yang akan datang. Pada prinsipnya, dana pensiun merupakan salah satu alternatif untuk memberikan jaminan kesejahteraan kepada karyawan. Adanya jaminan kesejahteraan tersebut memungkinkan karyawan untuk memperkecil masalah-masalah yang timbul dari risikorisiko yang akan dihadapi dalam perjalanan hidupnya, misalnya risiko kehilangan

\section{JIAKES}

Jurnal Ilmiah Akuntansi Kesatuan Vol. 6 No. 3, 2018 pg. 187-194 STIE Kesatuan ISSN $2337-7852$ 
Financial

Statement and

PSAK 18

188 pekerjaan, lanjut usia, dan kecelakaan yang mengakibatkan cacat tubuh atau bahkan mungkin kematian.

\section{Tujuan Penelitian}

1. Untuk mengetahui bagaimana perlakuan Program Manfaat Purnakarya yang diterapkan pada PT.BNI

2. Untuk mengetahui bagaimana penyajian Program Manfaat Purnakarya di Laporan Keuangan PT.BNI

3. Untuk mengetahui apakah perlakuan dan penyajian Program Manfaat Purnakarya PT.BNI telah sesuai dengan PSAK No. 18

\section{TINJAUAN PUSTAKA}

Pengertian Dana Pensiun menurut UU No. 11 Tahun 1992 tentang Dana Pensiun yaitu: Badan hukum yang mengelola dan menjalankan program yang menjanjikan manfaat pensiun. Sebagai suatu badan hukum, dana pensiun bertanggung jawab menghimpun dan mengelola dana milik peserta program pensiun.

\section{Program Pensiun Iuran Pasti (PPIP)}

Menurut Dwi Martani $(2015,293)$ Program iuran pasti adalah suatu program imbalan pascakerja di mana pemberi kerja membayar iuran sebesar jumlah yang sudah ditetapkan kepada Dana pensiun, namun jumalah imbalan yang akan dibayarkan tidak ditentukan karena tergantung dari ketersediaan aset program. Pada program ini, pemberi kerja tidak memiliki kewajiban hukum atau kewajiban konstruktif untuk membayar iuran lebih lanjut jika Dana Pensiun tidak memiliki aset (dana) yang cukup untuk membayar seluruh imbalan kerja terkait dengan jasa yang diberikan oleh pekerja pada periode berjalan dan periode sebelumnya.

\section{Program Pensiun Manfaat Pasti (PPMP)}

Menurut Dwi Martani $(2015,294)$ Program imbalan pasti adalah: Suatu program imbalan pascakerja di mana pemberi kerja wajib membayar sesuai dengan imbalan yang disepakati bagi pekerja saat selesai masa kerja nanti. Pemberi kerja memiliki kewajiban hukum atau kewajiban konstruktif untuk membayar iuran lebih lanjut jika Dana Pensiun tidak memiliki aset (dana) yang cukup untuk membayar seluruh imbalan kerja sebesar nilai yang telah disepakati. Oleh karena itu, jumalah iuran yang harus dibayar perusahaan tiap periode tidak dapat ditentukan, tergantung dari kondisi aset program.

\section{Penialain Aset Purnakarya}

Berdasarkan PSAK 18 paragraf 31 . Investasi program manfaat purnakarya harus diakui pada nilai wajar. Pada kasus surat berharga yang diperdagangkan, maka nilai wajar adalah nilai pasar. Pada investasi program purnakarya yang dimiliki seandainya estimasi nilai wajar tidak mungkin, maka pengungkapan harus dibuat berisi alasan mengapa nilai wajar tidak dapat digunakan. Berdasarkan PSAK 18 paragraf 33. Laporan keuangan program manfaat purnakarya yang berupa manfaat pasti atau iuran pasti, berisi informasi berikut ini:

1. Laporan perubahan aset neto tersedia untuk manfaat purnakarya;

2. Ringkasan dari kebijakan akuntansi yang signifikan;dan

3. Penjelasan mengenai program purnakarya dan pengaruh setiap perubahan program purnakarya selama periode tersebut.

Berdasarkan PSAK 18 paragraf 34. Laporan keuangan yang disediakan oleh program manfaat purnakarya termasuk berikut ini, jika memungkinkan:

1. Laporan aset neto tersedia untuk manfaat purnakarya mengungkapkan:

a. Aset pada akhir periode bersangkutan sesuai klasifikasinya;

b. Dasar penilaian aset;

c. Rincian setiap investasi tunggal yang melebihi $5 \%$ dari aset neto tersedia untuk manfaat purnakarya atau 5\% untuk setiap kelas atau jenis surat berharga;

d. Rincian setiap investasi pemberi kerja; dan

e. Liabilitas kecuali nilai kini aktuaria atas manfaat purnakarya terjanji; 
2. Laporan perubahan aset neto tersedia untuk manfaat purnakarya menyajikan hal-hal sebagai sebagai berikut: Iuran pemberi kerja; Iuran karyawan; Pendapatan investasi seperti bunga dan deviden; Pendapatan lain-lain; Manfaat yang dibayarkan dan terutang (analisis misalnya purnakarya, kematian dan cacat, serta pembayaran secara lumpsum); Beban administrasi; Beban lain-lain; Pajak penghasilan Laba rugi pelepasan investasi dan perubahan nilai investasi; dan Transfer dari dan untuk program purnakarya lain; Penjelasan mengenai kebijakan pendanaan;

3. Untuk program manfaat pasti, nilai kini aktuaria atau manfaat terjanji yang membedakan antara manfaat telah menjadi hak (vested benefits) dan manfaat belum menjadi hak (non-vested benefits) berdasarkan manfaat terjanji sesuai persyaratan program purnakarya, jasa yang diberikan pada tanggal pelaporan dan menggunakan tingkat gaji kini atau tingkat gaji proyeksi; informasi ini termasuk lampiran laporan aktuaris yang disajikan bersama dengan laporan keuangan terkait; dan

4. Untuk program manfaat pasti, penjelasan signifikan mengenai asumsi aktuaris yang dibuat dan metode yang digunakan untuk menghitung nilai kini aktuaria atas manfaat purnakarya terjanji.

Pada program manfaat pasti informasi disajikan dalam salah satu format berikut, yang mencerminkan perbedaan praktek pengungkapan dan penyajian informasi aktuaris.

1. Suatu laporan dimasukkan kedalam laporan keuangan yang memperlihatkan aset neto tersedia untuk manfaat purnakarya, nilai aktuaria atas manfaat purnakarya terjanji, dan hasil surplus atau defisit.

2. Laporan keuangan termasuk laporan aset neto tersedia untuk manfaat purnakarya dan laporan perubahan aset tersedia untuk manfaat purnakarya.

3. Laporan keuangan termasuk laporan aset neto tersedia untuk manfaat purnakarya dan laporan peubahan aset neto tersedia untuk manfaat purnakarya dengan menggunakan nilai kini aktuaria atas manfaat purnakarya terjanji yang terdapat dalam laporan aktuaris terpisah.

\section{Pengungkapan}

Berdasarkan PSAK 18 paragraf 33. Laporan keuangan program manfaat purnakarya yang berupa manfaat pasti atau iuran pasti, berisi informasi berikut ini:

a) Laporan perubahan aset neto tersedia untuk manfaat purnakarya.

b) Ringkasan dari kebijakan akuntansi yang signifikan.

c) Penjelasan mengenai program purnakarya dan pengaruh setiap perubahan program purnakarya selama periode tersebut.

Berdasarkan PSAK 18 paragraf 34. Laporan keuangan yang disediakan oleh program manfaat purnakarya termasuk berikut ini, jika memungkinkan:

a) Laporan aset neto tersedia untuk manfaat purnakarya mengungkapkan:

1) Aset pada akhir periode bersangkutan sesuai klasifikasinya.

2) Dasar penilaian aset.

3) Rincian setiap investasi tunggal yang melebihi 5\% dari aset neto tersedia untuk manfaat purnakarya atau 5\% untuk setiap kelas atau jenis surat berharga.

4) Rincian setiap investasi pemberi kerja.

5) Liabilitas kecuali nilai kini aktuaria atas manfaat purnakarya terjanji.

b) Laporan perubahan aset neto tersedia untuk manfaat purnakarya menyajikan hal-hal sebagai sebagai berikut: Iuran pemberi kerja. Iuran karyawan. Pendapatan investasi seperti bunga dan deviden. Pendapatan lain-lain; Manfaat yang dibayarkan dan terutang (analisis misalnya purnakarya, kematian dan cacat, serta pembayaran secara lumpsum). Beban administrasi. Beban lain-lain. Pajak penghasilan. Laba rugi pelepasan investasi dan perubahan nilai investasi. Transfer dari dan untuk program purnakarya lain.

c) Penjelasan mengenai kebijakan pendanaan.

d) Untuk program manfaat pasti, nilai kini aktuaria atau manfaat terjanji yang membedakan antara manfaat telah menjadi hak(vested benefits) dan manfaat belum menjadi hak (non-vested benefits) berdasarkan manfaat terjanji sesuai persyaratan 
Financial

Statement and

PSAK 18

190

program purnakarya, jasa yang diberikan pada tanggal pelaporan dan menggunakan tingkat gaji kini atau tingkat gaji proyeksi; informasi ini termasuk lampiran laporan aktuaris yang disajikan bersama dengan laporan keuangan terkait.

e) Untuk program manfaat pasti, penjelasan signifikan mengenai asumsi aktuaris yang dibuat dan metode yang digunakan untuk menghitung nilai kini aktuaria atas manfaat purnakarya terjanji.

Berdasarkan PSAK 18 paragraf 35. Pelaporan program manfaat purnakarya beris penjelasan atas program purnakarya, komponen laporan keuangan atau laporan keuangan tersendiri. Laporan tersebut berisi hal-hal berikut ini:

a) Nama pemberi kerja dan kelompok karyawan yang menjadi peserta program manfaat purnakarya;

b) Jumlah peserta yang menerima manfaat purnakarya dan jumlah peserta lain yang diklasifikasikan dengan tepat;

c) Jenis program purnakarya, program iuran pasti atau program manfaat pasti;

d) Catatan untuk mengetahui apakah peserta mempunyai kontribusi pada program purnakarya;

e) Penjelasan kewajiban manfaat purnakarya kepada peserta;

f) Penjelasan persyaratan penghentian setiap program purnakarya; dan

g) Perubahan dalam huruf (a) sampai (f) pada periode pelaporan tercakup dalam laporan.

Hal yang biasa dilakukan adalah mengacu dokumen lain yang tersedia untuk pengguna laporan keuangan dimana program purnakarya telah dijelaskan dan hanya memasukkan informasi setelah tanggal neraca.

\section{METODE PENELITIAN}

Penelitian ini dilakukan di PT Bank Negara Indonesia (Persero) Tbk. Beralamat di Jln. Jend. Sudirman Kav. 1 Jakarta 10220, Indonesia. Adapun sumber dan informasi dalam pengumpulan data adalah sebagai berikut:

1. Studi Kepustakaan.

Salah satu bentuk penelitian yang dilakukan untuk memperoleh informasi dan data yang diperlukan berdasarkan buku-buku atau literatur sehingga memperoleh pengertian teoritis yang berguna untuk proposal skripsi ini dan untuk menganalisis data yang diperoleh dari tempat lokasi penelitian.

2. Studi Lapangan.

Prosedur pengumpulan data dengan cara memperoleh data dan informasi secara langsung dari perusahaan dan dari data catatan serta arsip perusahaan.

3. Observasi.

Prosedur pengumpulan data yang dilakukan dengan cara mengadakan pengamatan secara langsung pada objek penelitian dan mencatat semua data yang diperlukan pada waktu melakukan penelitian pada perusahaan.

4. Wawancara.

Prosedur pengumpulan data yang dilakukan dengan cara meminta keterangan dari pihak perusahaan guna memperoleh gambaran mengenai perusahaan.

5. Internet Browsing.

Metode pengumpulan data melalui situs-situs internet untuk memperoleh informasi dan data mengenai perusahaan guna untuk melengkapi pembahasan penelitian dan analisa.

Analisis data dilakukan dengan menggunakan metode kualitatif deskriptif komparatif yaitu suatu metode dengan mengumpulkan data, disusun, diinterprestasikan dan membandingkan laporan keuangan di perusahaan dan menurut PSAK No. 18. Metode analisis yang digunakan adalah metode deskriptif. Teknik analisis data dilakukan dengan tahap-tahap sebagai berikut:

1. Reduksi Data, yaitu proses pemilihan, pemusatan perhatian pada penyederhanaan data-data yang muncul dari catatan-catatan tertulis dilapangan. 
2. Penyajian Data, yaitu penyusunan informasi yang kompleks ke dalam suatu bentuk yang sistematis, sehingga menjadi lebih selektif dan sederhana serta memberikan kemungkinan adanya penarikan kesimpulan data.

3. Data-data yang telah ada kemudian dibandingkan dengan PSAK No. 18 yang berkaitan dengan Program Pensiun PT. BNI.

4. Menganalisis hasil dari perbandingan PSAK No. 18 dengan data yang diperoleh dari perusahaan.

5. Menarik kesimpulan, yaitu merupakan tahap akhir dalam proses analisis data.

\section{HASIL DAN PEMBAHASAN \\ Program Iuran Pasti BNI}

Dana Pensiun Lembaga Keuangan Bank BNI adalah salah satu Bank yang menyelenggarakan Program Pensiun Iuran Pasti dengan aktifitas pokok menyelenggarakan Program Pensiun yang besar iurannya ditetapkan berdasarkan kemampuan peserta. Program Pensiun yang diselenggarakan oleh Dana Pensiun Lembaga Keuangan (DPLK) Bank BNI memberikan manfaat pensiun yang akan diterima setelah peserta memasuki usia pensiun berdasarkan besarnya iuran, lama kepesertaan dan tingkat pertumbuhan dana selama masa kepesertaan. Manfaat Pensiun dibayar atas dasar bentuk pensiun dengan Cash Refund / Pengembalian Tunai. Cash Refund / Pengembalian Tunai adalah : Jika peserta meninggal dunia pada usia pensiun maka dana yang dikembalikan kepada Ahli Waris adalah sebesar Premi tunggal dikurangi manfaat pensiun yang telah dibayarkan.

\section{Program BNI Simponi}

Tidak hanya pegawai negeri sipil (PNS) yang memiliki dana pensiun, pegawai swasta atau masyarakat umum lainnya juga bisa memiliki dana pensiun dengan menggunakan layanan Simponi milik Bank Negara Indonesia (BNI). BNI Simponi adalah layanan program pensiun yang diselenggarakan oleh Dana Pensiun Lembaga Keuangan PT. Bank Negara Indonesia (Persero) Tbk (DPLK BNI) sejak tahun 1994 berdasarkan Undang-Undang Nomor 11 Tahun 1992 tentang Dana Pensiun. Siapa pun Anda, bisa menjadi peserta BNI Simponi. BNI Simponi bisa diikuti oleh seluruh lapisan masyarakat apapun profesinya, baik itu pegawai negeri, pegawai swasta, pegawai BUMN/BUMD, dokter, notaris, konsultan, akuntan, pengacara, arsitek, pedagang, petani, buruh, mahasiswa dan lain sebagainya yang menginginkan kesejahteraan di masa purna tugas.

Penjabaran Paragraf 34 PSAK No. 18 mengenai Laporan Aset Neto dan Laporan Perubahan Aset Neto di BNI.

\section{Laporan Aset Neto}

a. Aset pada akhir periode bersangkutan sesuai klasifikasinya. Didalam penyusunan laporan aset neto lebih dirinci perkiraan-perkiraan yang ada dengan klasifikasi sebagai berikut: Aset : A. Investasi B. Aset lancar di luar investasi

a. Dasar penilaian aset

1. deposito berjangka pada Bank, BPR, dan BPRS, termasuk deposit on call dan deposito yang berjangka waktu kurang dari atau sama dengan 1 (satu) bulan berdasarkan nilai nominal;

2. sertifikat deposito pada Bank berdasarkan nilai tunai;

3. saham:

a) dalam hal saham aktif diperdagangkan di bursa efek berdasarkan nilai pasar dengan menggunakan informasi harga penutupan terakhir di bursa efek tempat saham tersebut tercatat dan diperdagangkan; atau

a) dalam hal saham tidak aktif diperdagangkan di bursa efek berdasarkan nilai wajar yang ditetapkan oleh lembaga penilaian harga efek yang telah memperoleh izin usaha dari Otoritas Jasa Keuangan atau lembaga penilaian harga efek yang telah diakui secara internasional; 
Financial

Statement and

PSAK 18

192 b) obligasi korporasi yang tercatat di bursa efek berdasarkan nilai wajar yang ditetapkan oleh lembaga penilaian harga efek yang telah memperoleh izin usaha dari Otoritas Jasa Keuangan atau lembaga penilaian harga efek yang telah diakui secara internasional;

c) surat berharga yang diterbitkan oleh Negara Republik Indonesia berdasarkan nilai wajar yang ditetapkan oleh lembaga penilaian harga efek yang telah memperoleh izin usaha dari Otoritas Jasa Keuangan atau lembaga penilaian harga efek yang diakui secara internasional.

b. Rincian setiap investasi tunggal yang melebihi $5 \%$ dari aset neto tersedia untuk manfaat purnakarya atau $5 \%$ untuk setiap kelas atau jenis surat berharga.

Berikut adalah hasil perhitungan persentase surat berharga negara dibagi dengan aset neto.

\begin{tabular}{lll} 
Surat Berharga Negara & $\mathrm{Rp} 1.303 .068 .544 .466$ & $\mathrm{Rp} 1.193 .896 .348 .552$ \\
Aset Neto & $\mathrm{Rp} 8.227 .479 .535 .741$ & $\mathrm{Rp7} .322 .921 .138 .244$ \\
\cline { 2 - 3 } Persentase & $15.84 \%$ & $16.30 \%$ \\
\hline \hline
\end{tabular}

Ini menunjukkan bahwa surat berharga negara melebihi $5 \%$ dari aset neto tersedia untuk manfaat purnakarya.

d. Rincian setiap investasi pada pemberi kerja

Sesuai dengan arahan investasi yang ditetapkan oleh Pendiri, investasi ditempatkan dalam bentuk deposito berjangka, obligasi dari institusi-institusi tertentu, sukuk, Surat Berharga Negara dan reksadana selama jangka waktu tertentu yang telah disetujui oleh Pengurus DPLK BNI.

Untuk tujuan penyusunan laporan aset neto dan laporan perubahan aset neto, investasi DPLK BNI dinilai sebagai berikut:

- Deposito berjangka dinilai berdasarkan nilai nominal.

- Surat Berharga Negara berupa obligasi yang diperjualbelikan di Bursa Efek Indonesia, dinilai berdasarkan nilai pasar pada tanggal laporan.

- Obligasi dari institusi-institusi tertentu dan sukuk, dinilai berdasarkan nilai pasar pada tanggal laporan.

- Reksadana dinilai berdasarkan nilai aset bersih pada tanggal laporan. Seluruh deposito berjangka yang dimiliki oleh DPLK BNI mempunyai jatuh tempo yang pendek, sehingga nilai tercatat atas deposito berjangka mendekati nilai wajarnya.

Dalam neraca, investasi disajikan dengan menggunakan harga perolehan. Selisih antara nilai perolehan dan nilai wajar disajikan di neraca pada akun "Selisih Penilaian Investasi" dan akun lawan (contra account) "(Beban)/Pendapatan Yang Belum Direalisasi".

e. Liabilitas selain nilai kini aktuaria dari manfaat purnakarya terjanji.

Liabilitas di luar liabilitas Manfaat Pensiun untuk tujuan penyusunan laporan keuangan aset neto dan perubahan aset neto, investasi DPLK BNI dinilai sebagai berikut:

1) Deposito berjangka berdasarkan nilai nominal.

2) Surat Berharga Negara berupa obligasi yang diperjualbelikan di Bursa Efek Indonesia, dinilai berdasarkan nilai pasar pada tanggal laporan.

3) Obligasi dari institusi-institusi tertentu dan sukuk, dinilai berdasarkan nilai pasar pada tanggal pelaporan.

4) Reksadana dinilai berdasarkan nilai aset bersih pada tanggal laporan

Seluruh deposito berjangka yang dimiliki DPLK BNI mempunyai jatuh tempo yang pendek, sehingga nilai tercatat atas deposito berjangka mendekati nilai wajarnya. Adapun liabilitas manfaat pensiun dari DPLK BNI, sebagai berikut:

1. Akumulasi iuran, dicatat berdasarkan akumulasi dana akrual yang telah dihimpun dari para peserta. 
2. Akumulasi hasil usaha, merupakan akumulasi hasil investasi dari dana peserta setelah dikurangi dengan beban investasi, operasional, dan lain-lain.

3. Pengalihan dana dari dana pensiun lainnya, dicatat berdassarkan jumlah actual yang dialihkan ke DPLK BNI.

\section{Laporan Perubahan Aset Neto}

a. Iuran pemberi kerja dan iuran pekerja

Berdasarkan persyaratan-persyaratan pada DPLK BNI, setiap pemberi kerja atau

peserta perorangan akan membayar iuran atas nama peserta. Pemberi kerja atau peserta perorangan dapat memilih cara-cara pembayaran iuran sebagai berikut:

- sejumlah persentase tertentu dari penghasilan peserta;

- sejumlah pembayaran tertentu untuk setiap peserta.

Iuran peserta dapat berupa iuran dari pemberi kerja yang bertanggung jawab sepenuhnya atas iuran, atau iuran peserta sendiri dan pemberi kerja atas nama peserta, dimana peserta akan membayar sebagian iuran melalui pemotongan gaji peserta tersebut.

Iuran peserta dapat berlanjut hingga peserta mencapai usia pensiun yang dipilih oleh peserta (sekurang-kurangnya 45 tahun). Pada usia yang dipilih tersebut, manfaat pensiun akan dibayarkan sesuai dengan Undang- Undang Dana Pensiun, melalui suatu kombinasi pembayaran sekaligus dan kontrak anuitas yang dibeli oleh peserta.

b. Sama dengan poin a.

c. Penghasilan investasi seperti bunga dan dividen

Pendapatan investasi dan beban diakui atas dasar akrual.

d. Penghasilan lain

Ada penghasilan lain di dalam laporan perubahan aset neto yaitu seperti kenaikan (penurunan) niali investasi; iuran; pendapatan lain diluar investasi; dan pengalihan dana dari dana pensiun lain.

e. Manfaat yang dibayarkan atau terutang (analisis, misalnya purnakarya, kematian dan cacat, serta pembayaran secara lumpsum)

Berikut adalah pembayaran manfaat pensiun:

Saldo awal tahun

Penerimaan iuran

Pembayaran manfaat pensiun

Penarikan iuran

Pengalihan dana ke dana pensiun lain

Hasil usaha neto

Pengalihan dana dari dana pensiun lain

Saldo akhir tahun

\begin{tabular}{|c|c|}
\hline 2013 & 2012 \\
\hline Rp 7.147.850.511.938 & Rp 6.021.155.871.334 \\
\hline $\operatorname{Rp} 1.516 .579 .145 .191$ & $\operatorname{Rp} 1.296 .985 .040 .198$ \\
\hline$\left(\begin{array}{ll}R p & 642.884 .604 .315\end{array}\right)$ & $(\operatorname{Rp} 434.180 .405 .094)$ \\
\hline$\left(\begin{array}{ll}R p & 132.838 .649 .643\end{array}\right)$ & (Rp 113.109 .118 .192$)$ \\
\hline 3.275 .606 .940$)$ & $30.616 .228 .638)$ \\
\hline $\mathrm{Rp} 7.885 .430 .796 .231$ & Rp 6.740.235.159.608 \\
\hline $\begin{array}{ll}\mathrm{Rp} & 509.693 .653 .861\end{array}$ & $\mathrm{Rp} \quad 403.685 .244 .164$ \\
\hline 1.135 .895 .645 & 3.930 .108 .166 \\
\hline $\mathrm{Rp} 8.396 .260 .345 .737$ & $\mathrm{Rp} 7.147 .850 .511 .938$ \\
\hline
\end{tabular}

f. Beban administrasi

Pendapatan investasi dan beban diakui atas dasar akrual.

g. Beban lain-lain

Pendapatan investasi dan beban diakui atas dasar akrual.

h. Laba rugi pelepasan investasi dan perubahan nilai investasi

Tidak ada laba rugi pelepasan investasi.

i. Transfer dari dan untuk program purnakarya lain.

Dana yang ditransfer dari dana pensiun lain merupakan akumulasi kontribusi yang dialihkan dari dana pensiun lain. Dana yang diterima dari dana pensiun lain selama tahun berjalan adalah sebagai berikut:

Toal pengalihan dana dari dana pensiun lain adalah Rp. 1.135.895.645 (2013) dan Rp. 3.930.108.166 (2012)

\section{PENUTUP}

Berdasarkan hasil pembahasan diatas maka dapat disimpulkan sebagai berikut: 
Financial

Statement and

PSAK 18

194

1. Perlakuan Program Manfaat Purnakarya yang diterapkan pada PT.BNI

a. PT. BNI menerapkan program iuran pasti dimana jumlah yang dibayarkan sebagai manfaat purnakarya ditetapkan berdasarkan iuran ke suatu dana bersama pendapatan investasi selanjutnya. Dalam program ini termasuk program iuran pasti yang diatur dalam peraturan dan perundang-undangan yang berlaku.

b. BNI Simponi adalah layanan program pensiun yang diselenggarakan oleh Dana Pensiun Lembaga Keuangan PT. Bank Negara Indonesia (Persero) Tbk (DPLK BNI) sejak tahun 1994 berdasarkan Undang-Undang Nomor 11 Tahun 1992 tentang Dana Pensiun. Siapa pun, bisa menjadi peserta BNI Simponi. BNI Simponi bisa diikuti oleh seluruh lapisan masyarakat apapun profesinya, baik itu pegawai negeri, pegawai swasta, pegawai BUMN/BUMD, dokter, notaris, konsultan, akuntan, pengacara, arsitek, pedagang, petani, buruh, mahasiswa dan lain sebagainya yang menginginkan kesejahteraan di masa purna tugas.

2. Penyajian Program Manfaat Purnakarya di Laporan Keuangan Dana Pensiun pada tahun 2012-2013 PT. Bank Negara Indonesia (Persero) telah sesuai dengan Pernyataan Standar Akuntansi (PSAK) No. 18.

3. Penyajian didalam PSAK No. 18 dalam paragraf 34 telah sesuai kecuali nomor 2 huruf (i) yang tidak sesuai.

\section{DAFTAR PUSTAKA}

Dwi Martani, S. V. (2015). Akuntansi Keuangan Menengah (Berbasis PSAK) (Vol. 2). Jakarta: Salemba Empat.

Ikatan Akuntansi Indonesia. (2017). PSAK 18 : Akuntansi dan Pelaporan Program Manfaat Purnakarya. Jakarta: IAI.

Kalkulator Dana Hari Tua. (2017). Dipetik 07 10, 2018, dari http://app.bnilife.co.id/web/tht.htm

Nussy, A. F. (2014). Analisis Penerapan PSAK No.18 Mengenai Akuntansi Dana Pensiun Pada PT. Taspen Cabang Manado.

Otoritas Jasa Keuangan Republik Indonesia. (2015). Statistik Dana Pensiun 2015. Direktorat Statistik dan Informasi IKNB Otoritas Jasa Keuangan Republik Indonesia.

PERATURAN OTORITAS JASA KEUANGAN NOMOR 3/POJK.05/2015. (t.thn.). INVESTASI DANA PENSIUN.

PERATURAN PEMERINTAH REPUBLIK INDONESIA NOMOR 45 TAHUN 2015. (t.thn.). PENYELENGGARAAN PROGRAM JAMINAN PENSIUN.

Puspitasari, L. I., \& Poputra, A. T. (2016). Evaluasi Penerapan Standar Akuntansi Keuangan No. 18 Tentang Akuntansi dan PelaporanManfaat Purnakarya pada PT. BNI.

Sari, E. I. (2014). Evaluasi Penerapan Akuntansi Dana Pensiun dan Pengaruhnya Terhadap Penyajian Laporan Keuangan Ditinjau dari Pihak Pemberi Kerja (Studi Kasus pada PDAM Tirta Pakuan Kota Bogor).

Setiawati, D. P. (2016). Analisis Program Manfaat Purnakarya Berdasarkan PSAK Nomor 18 Pada Dana Pensiun Semen Gresik.

Simbabrash, M., Charity, M., \& Lilian, N. (2014). Pension Fund Size (Asset Size) and Fund Investment.

Simulasi BNI Simponi. (2018). Dipetik 07 15, 2018, dari http://www.bni.co.id/id$\mathrm{id} /$ personal/simulasi/bnisimponi

Stice, E. K. (2011). Akuntansi Keuangan (16 ed., Vol. 2). Jakarta: Selemba Empat.

Undang-Undang Republik Indonesia Nomor 11 Tahun 1992 . (t.thn.). Dana Pensiun.

Undang-Undang Republik Indonesia Nomor 13 Tahun 2003. (t.thn.). Tenaga Kerja.

Undang-Undang Republik Indonesia Nomor 14 Tahun 2004. (t.thn.). Sistem Jaminan Sosial Nasional. 